\title{
Outer membrane antigens of oral Treponema species
}

\author{
B. D. TALL* and R. K. NAUMAN†
}

Department of Microbiology, University of Maryland Dental School, Baltimore, MD 21201, USA

\begin{abstract}
Summary. Outer membrane (OM) antigens of several oral treponemes were studied. SDSPAGE revealed a $56-58-\mathrm{kDa}$ protein as a major component of isolated OM vesicles. Immunoblot analysis with eluted antibodies prepared from Treponema denticola ATCC 33520 recognised the 56-58-kDa protein, which was highly conserved in the $17 \mathrm{~T}$. denticola strains tested. The protein was also a component of a $T$. denticola desoxycholate-extractable, ethanol-soluble antigen (DES-Ag) but was not present in $T$. pectinovorum or $T$. vincentii ATCC 35580 and strain N9 whole-cell lysates. Electronmicroscopy of OM vesicles showed typical treponemal ultrastructure. Immunogold labelling of T. denticola ATCC 33520 with $T$. denticola ATCC 33520 -specific eluted antibodies recognised only the OM surface of the cell. These results suggest that the $56-58-\mathrm{kDa}$ antigen comprises surface-orientated epitopes and that this antigen may be specific for $T$. denticola.
\end{abstract}

\section{Introduction}

Oral anaerobic spirochaetes are unicellular, helical, motile bacteria, which differ morphologically from other oral prokaryotes by the presence of periplasmic flagella..$^{1-3}$ Taxonomically, they are classified in the genus Treponema. ${ }^{4}$ The outermost structure of the helical cell is a multilayered membrane referred to as the outer membrane (OM), outer envelope or outer sheath. The OM completely surrounds the protoplasmic cylinder, which consists of the cytoplasmic and nuclear regions enclosing the peptidoglycancytoplasmic membrane (cell wall-cell membrane) complex. Around the helical protoplasmic cylinder are wound the periplasmic flagella, which are enclosed by the $\mathrm{OM}$ and, thus, are located between this structure and the protoplasmic cylinder.

Microscopic and bacteriological studies have implicated oral anaerobic spirochaetes in the pathogenesis of chronic inflammatory periodontal disease, and there is evidence that these micro-organisms are associated with the subgingival microflora in diseased sites, whereas they are absent from or indiscernible in healthy sites. ${ }^{5-14}$ They are located in situ at the peripheral surfaces of plaque in direct contact with the epithelial tissue, where they interact with various host cells. ${ }^{15,16}$ There is direct evidence that these organisms invade the surrounding mucosal tissue and penetrate the underlying connective tissue in acute ulcerative gingivitis. ${ }^{17,18}$ Two species, $T$. vincentii and $T$. denti-

Received 23 Dec. 1992; revised version accepted 6 June 1993

* Present address: Microbial Ecology Branch, Division of Microbiology, Center for Food Safety and Applied Nutrition, Food and Drug Administration, 200 C Street SW, Washington, DC 20204, USA.

$\dagger$ Correspondence should be sent to Dr R. K. Nauman. cola, possess acetylglucosaminidase and trypsin-like protease enzymes, respectively. ${ }^{11,19,20}$ Recently, Siboo et $a .^{21}$ presented evidence that these spirochaetes secrete a phosphatidylcholine-hydrolysing phospholipase $\mathrm{C}$ enzyme. For these reasons, oral anaerobic spirochaetes may be involved in the initiation and progression of periodontal lesions by contributing to the destruction of the tissue ground substance and cellto-cell and cell-tc substratum binding.

In the study oi the pathogenic potential of oral anaerobic spirochaetes in chronic inflammatory periodontal disease, it is appropriate to evaluate the OM. Critical studies of various diseases caused by other spirochaetes, in particular Lyme disease ${ }^{22}$ and syphilis, ${ }^{23,24}$ have shown that the OM antigens of these spirochaetes are important in pathogenesis. Masuda and Kawata ${ }^{25}$ showed that the OM of a strain of $T$. denticola had a major protein with an apparent mol. wt of c. $62 \mathrm{kDa}$. Electronmicroscopy revealed that the OM was composed of a triple-layered vesicle with a polygonal array. Simonson et al. ${ }^{26}$ described the reaction of an immunogold-labelled monoclonal antibody which recognised a surface epitope of a strain of $T$. denticola and was specific for that species. Umemoto et $a l^{27}$ identified an OM protein of $T$. denticola with an apparent mol. wt of $53 \mathrm{kDa}$. Therefore, we examined strains of $T$. denticola, $T$. pectinovorum and $T$. vincentii for the presence and conservation of common OM antigens by an antibody adsorption and elution technique. The purpose of this report is to describe the structural location and immunological relationship of this antigen among strains of three species of oral treponemes and define its conservation within $T$. denticola. 
Table. Spirochaete strains studied

\begin{tabular}{ll}
\hline Species and strain* & \multicolumn{1}{c}{ Source } \\
\hline T. denticola & \\
ATCC 33520 & UMDS, AP \\
MS & UMDS, ANUG \\
DW & UMDS, ANUG \\
M1 & UMDS, ANUG \\
22 & UMDS, ANUG \\
23 & UMDS, ANUG \\
JD1 & R. Mink, WLC, tongue \\
JD3 & R. Mink, WLC, tongue \\
8 A & R. Mink, WLC, gingivitis \\
2513 & M. Listgarten, U. Pa. $\dagger$ \\
2519 & M. Listgarten, U. Pa. $\dagger$ \\
MRB & E. Hunter, CDC, healthy \\
CD1 & UMDS, unknown \\
JZ & UMDS, AP \\
ROSE & UMDS, ANUG \\
USA & UMDS, Rhesus monkey (Macaca mulata) \\
$\cdot$ & Periodontal disease, leukaemic \\
T. pectinovorum & \\
P2 & E. Canale-Parola, U. Mass. \\
T. vincentii & P. Hardy, JHU $\dagger$ \\
N9 & M. Listgarten, U. Pa $\dagger$ \\
ATCC 35580 &
\end{tabular}

UMDS, University of Maryland Dental School, Baltimore; WLC, Warner-Lambert Company, Morris Plains, NJ; U. Pa., University of Pennsylvania, Philadelphia; U. Mass., University of Massachusetts, Amherst; ATCC, American Type Culture Collection; AP, advanced periodontitis; ANUG, acute necrotising ulcerative gingivitis.

* $T$. denticola organisms were identified by periplasmic flagella arrangement (2-4-2), darkfield morphology and gas-liquid chromatography of metabolic end products. $T$. vincentii and $T$. pectinovorum were identified by periplasmic flagella arrangement (5-10-5 and 1-2-1, respectively), darkfield morphology and nutritional requirements.

$\dagger$ Oral health of individual from whom the organism was isolated was not defined.

\section{Materials and methods}

\section{Organisms and growth conditions}

The treponeme strains used in this study and their origins are listed in the table. $T$. denticola strains were cultivated as described previously ${ }^{28,29}$ and maintained on a semi-solid medium of PPLO broth without crystal violet (BBL Microbiology Systems, Cockeysville, MD, USA), plus cocarboxylase (Sigma) $15 \mu \mathrm{g} / \mathrm{ml}$, sterile rabbit serum (Gibco Laboratories, Grand Island, NY) $10 \%$, heat-inactivated at $56^{\circ} \mathrm{C}$ for $30 \mathrm{~min}$, sodium thioglycolate (Sigma) 0.05\%, and agar 0.1\%.

Stock cultures of $T$. pectinovorum strain P2 and $T$. vincentii strains $\mathrm{N} 9$ and ATCC 35580 were maintained on the media described previously for these species. ${ }^{29}$

All treponeme cultures were incubated at $37^{\circ} \mathrm{C}$. For broth cultures, the same media were prepared without the addition of agar and antibiotics.

\section{Antiserum preparation}

Specific rabbit antiserum was prepared against $T$. denticola ATCC 33520 by immunising New Zealand White rabbits once a week for 4 weeks with $2.5 \mathrm{ml}$ of a 5-7-day-old broth culture $(2.5 \times$
$10^{8}$ cells $/ \mathrm{ml}$ ) as described previously. ${ }^{29,30}$ Seven days after the final injection, blood was collected by cardiac puncture, and the serum was separated and stored at $-20^{\circ} \mathrm{C}$ until needed.

\section{$S D S-P A G E$}

The gels and solutions used were those previously described. ${ }^{29}$ Briefly, spirochaete isolates were harvested by centrifugation at $16000 \mathrm{~g}$ for $30 \mathrm{~min}$. The cell pellets were washed three times with $0 \cdot 1 \mathrm{M}$ Tris buffer (pH 6.8) and suspended in the same buffer to an optical density (OD) of 1.5 at $650 \mathrm{~nm}$. The cells were frozen and thawed four times, divided into $50-\mu 1$ fractions, and either stored at $-20^{\circ} \mathrm{C}$ or frozen and thawed a fifth time and used immediately. After boiling for $2 \mathrm{~min}$ in a mixture containing $0.5 \mathrm{M}$ Tris, SDS $2 \%$, 2-mercaptoethanol $5 \%$, sucrose $10 \%$, and bromophenol blue $0.001 \%$ (equal volumes of sample and buffer), $30 \mu$ of each cell lysate was added to wells of a $1.5-\mathrm{mm}$ thick vertical discontinuous polyacrylamide gel-acrylamide $5 \%$ stacking gel $(0 \cdot 125 \mathrm{M}$ Tris $\mathrm{HCl}$, pH 6.8) and $12.5 \%$ separating gel $(0.375 \mathrm{M}$ Tris $\mathrm{HCl}$, pH 8.8)-for electrophoresis (Model V16 system; Bethesda Research Laboratories, Gaithersburg, MD) at a constant voltage of $150 \mathrm{~V}$ in a Tris-glycine buffer (0.025 M Tris, 0.192 M glycine, $\mathrm{pH} 8 \cdot 3$ ) until the bromophenol blue tracking dye approached the bottom of the gel.

The gel was fixed for $2 \mathrm{~h}$ in an aqueous solution containing trichloroacetic acid $10 \% \mathrm{w} / \mathrm{v}$ and sulphosalicylic acid (Sigma) 5\% w/v, equilibrated for $1 \mathrm{~h}$ in an aqueous solution of methanol $25 \% \mathrm{v} / \mathrm{v}$ and acetic acid $5 \% \mathrm{v} / \mathrm{v}$ and stained for $6 \mathrm{~h}$ in Coomassie Brilliant Blue R-2050 0.1\% in the methanol-acetic acid solution. The gels were destained by soaking in the equilibration solution until the background was clear and photographed with Polaroid $55 \mathrm{P} / \mathrm{N}$ film. Approximate molecular sizes of the separated proteins were determined by the method of Weber and Osborne, ${ }^{31}$ with the following protein molecular size standards (in $\mathrm{kDa}$ ): myosin, $200 ; \beta$-galactosidase, 116.2 ; phospholipase $\mathrm{B}, 92.5$; bovine serum albumin, 66.2 ; ovalbumin, 45 ; carbonic anhydrase, 31 ; soybean trypsin inhibitor, 21.5; and lysozyme, 14.4 (BRL).

\section{Immunoblot analysis}

Immunoblot analysis was used to demonstrate the presence of shared OM antigens. SDS-separated antigens in polyacrylamide gels were transferred electrophoretically to a nitrocellulose membrane $(0.45-\mu \mathrm{m}$ pore size; Millipore) by the method of Towbin et al. ${ }^{32}$ in a Transblot electrophoresis system (BioRad, Richmond, CA, USA) with an electrode buffer of $25 \mathrm{~mm}$ Tris, $192 \mathrm{~mm}$ glycine and methanol $20 \% \mathrm{v} / \mathrm{v}, \mathrm{pH} 8.3$; the gel was placed nearest the cathode. After electrophoresis at $4^{\circ} \mathrm{C}$, with a voltage gradient of $10 \mathrm{~V} / \mathrm{cm}$ for $18 \mathrm{~h}$ or $60 \mathrm{~V} / \mathrm{cm}$ for $3 \mathrm{~h}$, antigens transferred to the nitrocellulose were detected by the technique of Tsang: ${ }^{33}$ the membranes were incubated with four 


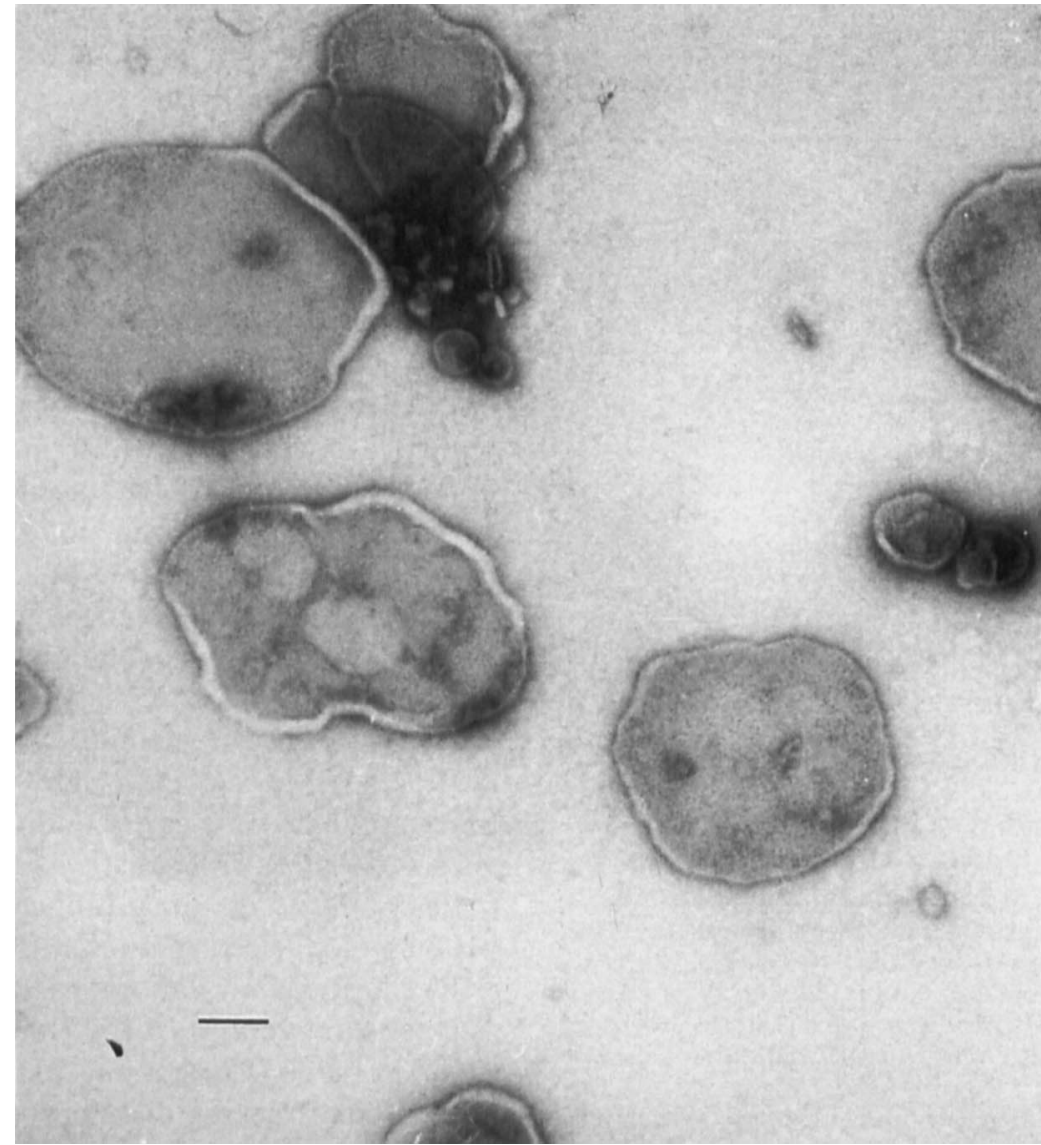

Fig. 1. Electronmicrograph of vesicles from typical OM preparation negatively stained with uranyl acetate. Note characteristic polygonal array. Bar represents $0 \cdot 1 \mu \mathrm{m}$.

washes of blocking solution (PBS-Tween 20 buffer$0 \cdot 01 \mathrm{M} \mathrm{Na}_{2} \mathrm{HPO}_{4}, 0 \cdot 15 \mathrm{M} \mathrm{NaCl}, \mathrm{pH} 7 \cdot 2$, with Tween 20 , Sigma, $0 \cdot 3 \%$ ) for $1 \mathrm{~h}$ at $40^{\circ} \mathrm{C}$ (it was later found that the blocking step could be eliminated) and then allowed to react with primary rabbit spirochaete antisera diluted in the same buffer for $18 \mathrm{~h}$ at $4^{\circ} \mathrm{C}$ with shaking. After washing with PBS-Tween buffer, bound rabbit antibodies were detected with goat anti-rabbit IgG conjugated with horseradish peroxidase (Jackson Immunoresearch Laboratories Inc., Avondale, PA, USA) and the complexes were demonstrated with an aqueous solution of 4-chloro-naphthol (Sigma) $0.33 \%$ and $\mathrm{H}_{2} \mathrm{O}_{2} 0.016 \%$ in PBS, $\mathrm{pH} 7.2$, incubated for $30 \mathrm{~min}$ at $25^{\circ} \mathrm{C}$. To ascertain optimal conditions for antigen-antibody reactions, nitrocellulose membranes containing $T$. denticola, $T$. pectinovorum and $T$. vincentii SDS-PAGE-separated antigens were probed with serial 10-fold dilutions of rabbit spirochaete antisera.

\section{Adsorption and elution of antibodies to surface spirochaetal antigens}

Antibodies were prepared selectively by combining the techniques of Wolf ${ }^{34}$ and Engleberg et al. $^{35}$ Formalin $37 \%$ was added to $60 \mathrm{ml}$ of a 5-7-day-old broth culture (final concentration, formalin $0.5 \%$ ). The cell suspension was incubated at $4^{\circ} \mathrm{C}$ for $1 \mathrm{~h}$; cells were harvested by centrifugation at $16000 \mathrm{~g}$ for $30 \mathrm{~min}$ at $4{ }^{\circ} \mathrm{C}$, washed twice with saline, and resuspended in $5 \mathrm{ml}$ of a 1 in 5 dilution of heat-inactivated $\left(56^{\circ} \mathrm{C}\right.$, $30 \mathrm{~min}$ ) rabbit anti-spirochaete serum. The cell-serum suspensions were incubated for $18 \mathrm{~h}$ with constant agitation at $4^{\circ} \mathrm{C}$. Antibody-bound cells were harvested by centrifugation at $16000 \mathrm{~g}$ for $15 \mathrm{~min}$ at $4^{\circ} \mathrm{C}$. The supernate, containing antibodies not bound to the surface of the cells, was aspirated and stored at $-20^{\circ} \mathrm{C}$ until needed. The antibody-bound cells were washed twice with saline, suspended in an elution buffer $(0 \cdot 2 \mathrm{M} \mathrm{NaCl}$ and $0.2 \mathrm{M}$ glycine $)$, and adjusted to $\mathrm{pH} 2 \cdot 8$. After incubation at room temperature for $30 \mathrm{~min}$ with constant agitation, and centrifugation at $16000 \mathrm{~g}$ for $15 \mathrm{~min}$, the supernate, containing the eluted antibodies

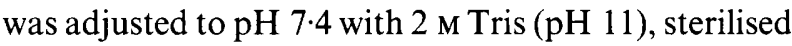
by filtration, and stored at $-20^{\circ} \mathrm{C}$ until needed.

\section{Desoxycholate-extractable, ethanol-soluble antigen (DES-Ag) preparation}

The DES-Ag from T. denticola ATCC 33520 was prepared as described previously. ${ }^{30,36,37}$ The final precipitate was resuspended in $10 \mathrm{ml}$ of phosphatebuffered saline (PBS), $\mathrm{pH} 7 \cdot 2$, vortex mixed, divided into $1-\mathrm{ml}$ volumes in sterile vials, and lyophilised. The antigen for SDS-PAGE and immunoblot analysis was prepared by reconstituting the contents of a vial with $1 \mathrm{ml}$ of sterile distilled water. Antigen concentration was determined by the method of Lowry et al. ${ }^{38}$ 


\section{Isolation of the $O M$}

OM vesicles from $T$. denticola ATCC 33520 were obtained by the method of Masuda and Kawata: ${ }^{25}$ 5-7-day-old cells were harvested from $5 \mathrm{~L}$ of culture,

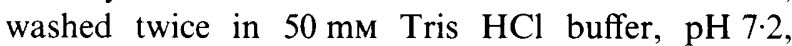
suspended in $60 \mathrm{ml}$ of the same buffer, containing $2 \mathrm{mM} \mathrm{MgCl}_{2}$ DNAseI (Worthington Diagnostics, Freehold, NJ, USA) $2 \mu \mathrm{g} / \mathrm{ml}$, and disrupted by 40 cycles of freezing in dry ice-acetone and thawing in tap water at c. $20^{\circ} \mathrm{C}$. After centrifugation at $10000 \mathrm{~g}$ for $10 \mathrm{~min}$ to remove unbroken cells and large cell debris, the supernate was centrifuged at $25000 \mathrm{~g}$ for $30 \mathrm{~min}$ to obtain a crude preparation of OM. The crude preparation was washed three times with Tris-HCl buffer and suspended in $40 \mathrm{ml}$ of $0 \cdot 1 \mathrm{M}$ sodium acetate$\mathrm{HCl}$ buffer, $\mathrm{pH} 3 \cdot 0$, to dissolve contaminating flagella, stirred for $2 \mathrm{~h}$ at $4^{\circ} \mathrm{C}$, and finally centrifuged at $25000 \mathrm{~g}$ for $30 \mathrm{~min}$. The resulting pellet was suspended in $500 \mu \mathrm{l}$ of Tris- $\mathrm{HCl}$ buffer, layered on a $35-50 \%$ linear sucrose density gradient prepared in the same buffer, and centrifuged at $100000 \mathrm{~g}$ for $2 \mathrm{~h}$. Ten-drop fractions were collected from the bottom of the tube and the absorbance at 280 and $260 \mathrm{~nm}$ was determined for each fraction. Fractions with high readings $(260 \mathrm{~nm})$ were pooled, diluted with Tris- $\mathrm{HCl}$ buffer, centrifuged at $25000 \mathrm{~g}$ for $30 \mathrm{~min}$, and washed four times. The resulting pellet was frozen and stored at $-20^{\circ} \mathrm{C}$ until needed. The procedure was evaluated by transmission electronmicroscopy and SDS-PAGE analysis.

\section{Electronmicroscopy}

Duplicate OM specimens were applied to formvar $0.25 \%$ carbon-coated 300-mesh copper grids for $1 \mathrm{~min}$. Excess fluid was removed with filter paper and the specimens were immediately stained with uranyl acetate $1 \%$, pH 4.0 , for $20-30 \mathrm{~s}$. Excess stain was removed and the grids were allowed to dry in air before examination in a Siemens IA transmission electronmicroscope at an accelerating voltage of $80 \mathrm{kV}$.

\section{Immunogold labelling}

A 5-day-old culture of $T$. denticola ATCC 33520 , grown as described previously, was harvested by centrifugation at $10000 \mathrm{~g}$ for $30 \mathrm{~min}$. The cell pellet was washed once with PBS, $\mathrm{pH} 7 \cdot 4$, and a cell suspension containing $c .10^{9}$ cells $/ \mathrm{ml}$ was prepared and placed on ice until used. One-ml volumes were placed in a pair of 2-ml Eppendorf centrifuge tubes (Brinkmann Instruments Inc., Sybron Corp., Westbury, NY, USA) and formalin $37 \%$ was added to give a final concentration of $1 \% \mathrm{v} / \mathrm{v}$; the suspensions were stored on ice for $1 \mathrm{~h}$. After fixation, the cells were centrifuged, washed with PBS, and resuspended to $1 \mathrm{ml}$. They were allowed to react for $1 \mathrm{~h}$ on ice with either eluted antibody or non-immune rabbit antisera, washed with PBS, resuspended to $1 \mathrm{ml}$, and treated with a 1 in 5 dilution of goat anti-rabbit IgG labelled with 10-nm colloidal gold particles (SPI Supplies, Inc., West Chester, PA, USA). After incubation for $1 \mathrm{~h}$, the cells were washed, resuspended as before, and negatively stained with sodium phosphotungstate $1 \%$, $\mathrm{pH} 6 \cdot 8$, for electronmicroscopy.

\section{Results}

\section{OM studies}

Isolated $\mathrm{OM}$ vesicles were characterised by electronmicroscopy and SDS-PAGE. Negatively stained preparations (fig. 1) revealed vesicles which, after acid treatment and sucrose gradient centrifugation, still possessed a typical polygonal array but were free of contaminating periplasmic flagella and cell-wall material. SDS-PAGE was used to follow the isolation of the OM from $T$. denticola ATCC 33520, and revealed a major component of the isolated vesicles as a 56-58-kDa protein (fig. 2). The OM vesicles had a buoyant density of $c .1 \cdot 15 \mathrm{~g} / \mathrm{cm}^{3}$ after centrifugation in a $35-50 \%$ linear sucrose density gradient.

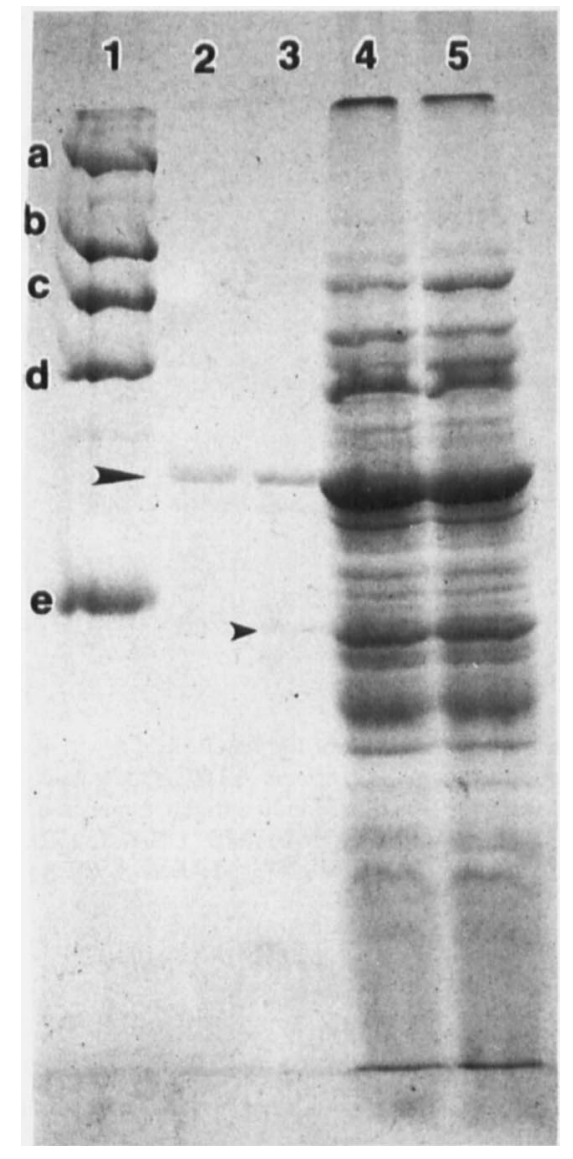

Fig. 2. SDS-PAGE electrophoretogram showing various steps in the isolation of OM vesicles from $T$. denticola ATCC 33520 . Lane 1 contains molecular size standards represented by (in kilodaltons) a myosin, $200 ; \mathbf{b}, \beta$-galactosidase, 116.2 ; c, phospholipase B, $92 \cdot 5$; d, bovine serum albumin, $66 \cdot 2$; e, ovalbumin, 45 . Lanes 2 and 3 are OM preparations after and before acid treatment, respectively. Note the presence of a major protein band of $56-58 \mathrm{kDa}$ in both preparations ( $\rightarrow$ ) and a minor band of $c .40 \mathrm{kDa}$ in the preparation before acid treatment $(>)$. Lanes 4 and 5 contain whole-cell lysate preparations after 40 cycles of freeze-thaw and before membrane isolation, respectively. 


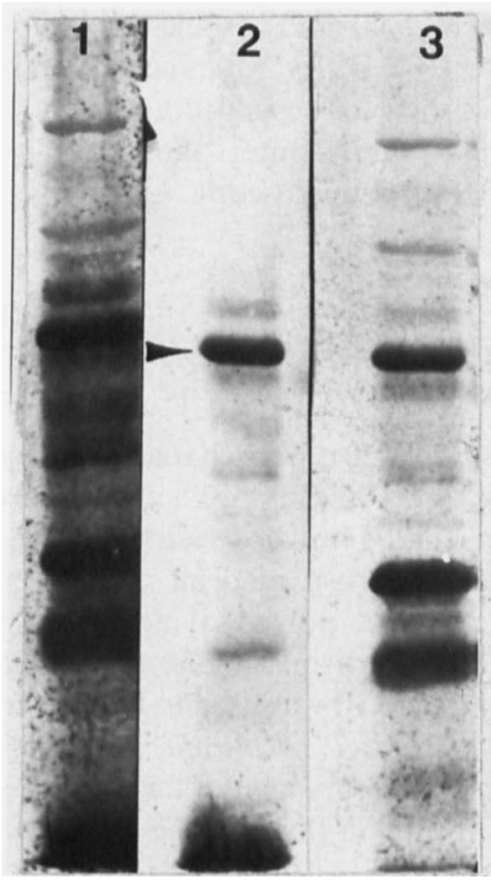

Fig. 3. Immunoblot analysis of reaction (1) unadsorbed antiserum (2) eluted antibodies, (3) adsorbed antibodies from $T$. denticola ATCC 33520 with $T$. denticola ATCC 33520 whole cell antigens ( $>$ 56-58-kDa antigen).

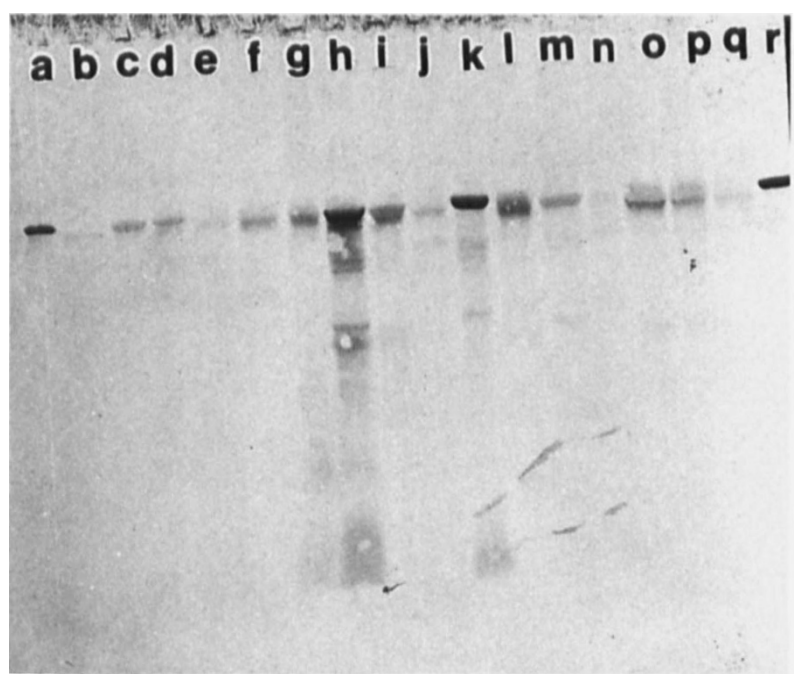

Fig. 4. Immunoblot analysis of the reaction of a 1 in 400 dilution of eluted antibodies from $T$. denticola ATCC 33520 with 16 strains of $T$. denticola and DES-ATCC 33520 antigen. Lanes a-q: $T$. denticola ATCC 33520, CD1, ATCC 33520, MS, USA, 23, 22, 2513, 2519, DW, JZ, 8A, ROSE, M1, JD1, JD3, MRB; r, DES-Ag $(50 \mu \mathrm{g} / \mathrm{ml})$.

\section{Antibody adsorption and elution studies}

Immunoblot analysis with eluted antibodies prepared against $T$. denticola ATCC 33520 was used to differentiate surface antigens from internal antigens and identify the spatial orientation of the $56-58-\mathrm{kDa}$ protein. One major antigen of $c$. 56-58 $\mathrm{kDa}$ was found (fig. 3). The reactions of antibodies not adsorbed and eluted are also shown in fig. 3. These antibodies recognised six other minor antigens ( 1 in 50 dilution); the unadsorbed serum recognised at least 16 antigens (fig. 3). In immunoblot analysis of eluted antibodies against antigens from other strains of $T$. denticola, the $56-58-\mathrm{kDa}$ antigen (fig. 4) was a major antigen of all

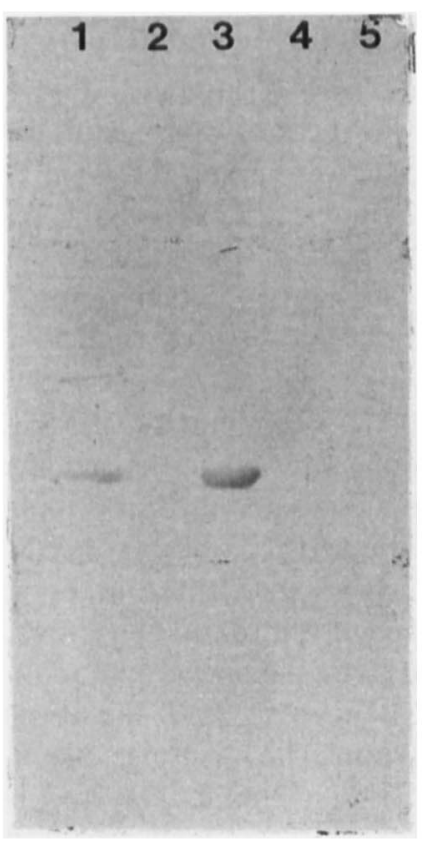

Fig. 5. Immunoblot analysis of the reaction of a 1 in 200 dilution of eluted antibodies from $T$. denticola ATCC 33520 with: 1, DES-Ag; 2, T. pectinovorum strain P2; 3, T. denticola ATCC 33520; 4 and 5 $T$. vincentii ATCC 33580 and strain N9 respectively.

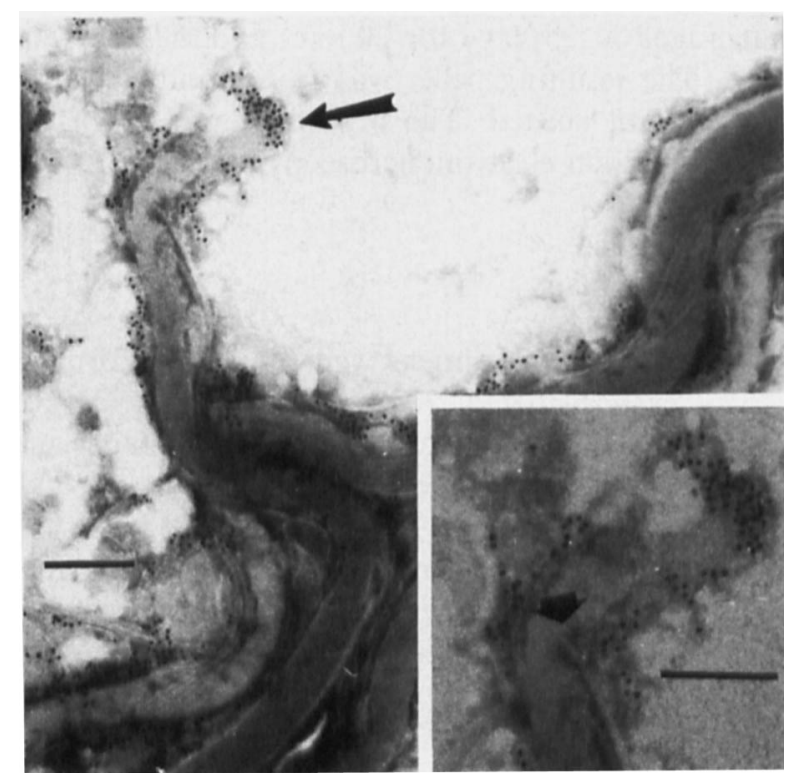

Fig. 6. Electronmicrograph of $T$. denticola ATCC 33520 labelled with eluted antibodies from $T$. denticola ATCC 33520 identified with a goat anti-rabbit IgG colloidal gold-labelled antibody (gold particle size $=10 \mathrm{~nm}$ ) negatively stained with sodium phosphotungstate $(\mathrm{pH} \mathrm{6.8)}$. Insert is enlargement of area indicated by Note gold particles binding to surface of outer membrane and absence of binding to periplasmic flagella ( $\phi$ in insert). Bar represents $0.25 \mu \mathrm{m}$.

whole-cell lysates of $T$. denticola. In addition, the $T$. denticola ATCC 33520-eluted antibodies recognised a 56-58-kDa antigen as a component of the DES-Ag antigen (fig. 4), a previously described $T$. denticola antigen. ${ }^{30}$ In contrast, the heterologous reaction of $T$. denticola ATCC 33520-eluted antibodies and whole-cell lysate antigens from $T$. pectinovorum and T. vincentii ATCC 33580 and strain N9 (fig. 5) did not indicate the presence of either antigen. This finding 
suggests that the $56-58-\mathrm{kDa}$ antigen may be specific for $T$. denticola.

\section{Surface labelling of T. denticola ATCC 33520}

Immunogold labelling of $T$. denticola ATCC 33520 , with eluted antibodies prepared from $T$. denticola ATCC 33520 cells, was performed to determine if the 56-58-kDa OM-associated antigen contained surface antigenic epitopes. The eluted antibody-immunogold complexes reacted only with the OM surface of the cell (fig. 6). No immune complexes reacted with either periplasmic flagella or the protoplasmic cylinder. These results suggest that the eluted antibodies specifically recognised a cell surface OM antigen.

\section{Discussion}

A previous report ${ }^{29}$ presented evidence that three species of oral anaerobic spirochaetes, $T$. denticola, $T$. pectinovorum and $T$. vincentii, possess speciesspecific SDS-PAGE differences. The data correlated well with those obtained by microscopic agglutination analysis of strains representing the three species. Microscopic agglutination analysis revealed no serological cross-reactivity or sharing of antigens, and SDS-PAGE showed obvious and overall differences among the three species; however, the electrophoretic migration of many polypeptide bands was similar. Subsequent evidence showed that these microorganisms share antigens that are not observable by microscopic agglutination analysis. ${ }^{29}$

The complex ultrastructure of the OM isolated from T. denticola ATCC 33520 was studied by electronmicroscopy of negatively stained preparations and was found to have a typical polygonal array and to be free of periplasmic flagella. Our finding that a $56-58$ $\mathrm{kDa}$ protein is a major component of the isolated $\mathrm{OM}$ agreed with that reported by Masuda and Kawata, ${ }^{25}$ but differed from that of Kropinski et al.$^{40}$ regarding the free-living spirochaete, Spirochaeta aurantia which contained four proteins of $26,36 \cdot 5,41$ and $48 \cdot 5 \mathrm{kDa}$ respectively. In a comparative freeze-fracture of $T$. pallidum and $S$. aurantia, Walker et al. ${ }^{41}$ reported great differences between the numbers of integral membrane proteins in the respective OM preparations, suggesting that the antigenic inertness of $T$. pallidum OM may be related to the lack of integral membrane proteins. They postulated that the low integral OM protein content reflects a specific evolutionary adaptation, which allows this organism to evade the human immune response during the course of the disease. Further studies are needed to determine if oral anaerobic spirochaetes possess similar properties that may suggest a positive role for these bacteria in chronic inflammatory periodontal disease. The apparent differences between $S$. aurantia and the hostadapted state of $T$. denticola may also be related to nutritional needs and the remoteness of the organism to the free-living state. Thus, the number of integral OM proteins may reflect the ability (or inability) of the organisms to gather energy and carbon sources from their particular ecological niche.

Surface antigens were differentiated from internal antigens by immunoblot analysis with eluted antibodies prepared from $T$. denticola ATCC 33520 . One major antigen of $c$. 56-58-kDa was recognised, but antibodies not adsorbed and eluted recognised six other minor antigens and unadsorbed serum recognised at least 16 antigens. In a study of the characterisation of the DES-Ag of four serotypes of $T$. denticola, Jacob and Nauman ${ }^{30}$ reported that the protein component of the DES-Ag comprised two polypeptides, of 58 and $31 \mathrm{kDa}$. In the present study, diluted T. denticola ATCC 33520-eluted antibodies recognised the 56-58-kDa major antigen of the wholecell lysate and of the DES-Ag, which were identical in their banding position. These results corroborate the findings of Jacob and Nauman ${ }^{30}$ and add strength to the argument that the $56-58-\mathrm{kDa}$ antigen is a surface antigen. However, the mol. wt of $56-58 \mathrm{kDa}$ for the OM protein reported here is different from that reported by Cockayne et al. ${ }^{42}$ and others. ${ }^{43-44}$ Cockayne et $a l .{ }^{42}$ reported that four major OM polypeptides, of 73, 68, 54 and $52 \mathrm{kDa}$, were isolated from T. denticola ATCC 33520 by a Triton X100 solubilisation procedure, whereas Yotis et al..$^{43}$ reported that, for three strains of $T$. denticola, OM preparations extracted by SDS contained polypeptides of 66,53 and $45 \mathrm{kDa}$. Although the $53-\mathrm{kDa}$ protein described by these authors may be a serovar-specific antigen, our results showed that the 56-58-kDa protein was speciesspecific. Nonetheless, the $56-58-\mathrm{kDa}$ OM protein reported here may be the same protein that both of these groups reported as 54 and $53 \mathrm{kDa}$, respectively; the assigned mol.wt is well within experimental error limits. However, without a comparative study involving all the isolation procedures used by the different groups, it is difficult to ascertain whether these proteins are truly one and the same. Cockayne et al ${ }^{42}$ noted that the 54-kDa protein may be a breakdown product of a larger, heat-modifiable polypeptide. Other findings ${ }^{44,45}$ suggest that the OM proteins may be involved in the binding of host serum proteins such as laminin, fibronectin and fibrinogen, or in the adherence to host tissues. Our finding that rabbit serum albumin in the growth medium was a component in whole-cell lysate preparations, suggests that this host protein is adsorbed to the spirochaete OM. ${ }^{46}$ Perhaps some of the inconsistencies in detecting OM antigens in different strains of $T$. denticola may be due to immunological masking of antigenic epitopes by adsorption of host proteins. The heterologous reaction of $T$. denticola ATCC 33520-eluted antibodies with other strains of $T$. denticola suggested that the 56-58$\mathrm{kDa}$ antigen was a major component of their wholecell lysate preparations. These results agree with those of Masuda and Kawata ${ }^{25}$ and Jacob and Nauman ${ }^{30}$ but contradict those of Umemoto et al., ${ }^{27,47,48}$ who 
described a $53-\mathrm{kDa}, \mathrm{OM}$-associated protein that was thought to be a strain-specific antigen. The data of Umemoto et al..$^{27,47,48}$ revealed the presence of this antigen in only one of three $T$. denticola antigen preparations. Our immunoblot data show the presence of a highly conserved $56-58-\mathrm{kDa}$ antigen in all 17 $T$. denticola strains. Furthermore, this antigen was found to be a component of the $T$. denticola common antigen, the DES-Ag. Agglutination studies of four different $T$. denticola serotypes reported by Jacob and Nauman $^{30}$ showed that the DES-Ag is composed of both common and strain-specific components. However, additional studies with other strains of T. denticola are needed to determine the conservation of their specific antigens.

\section{References}

1. Canale-Parola E. Physiology and evolution of spirochetes. Bacteriol Rev 1977; 41 : 181-204.

2. Holt SC. Anatomy and chemistry of spirochetes. Microbiol Rev 1978; 42: 114-160.

3. Limberger RJ, Charon NW. Antiserum to the 33,000-dalton periplasmic-flagellum protein of "Treponema phagedenis" reacts with other treponemes and Spirochaeta aurantia. J Bacteriol 1986; 168: 1030-1032.

4. Canale-Parola E. Order 1. Spirochaetales Buchanan 1917, 163 AL. In: Krieg NR, Holt JG (eds) Bergey's Manual of systematic bacteriology, vol 1, Baltimore, Williams and Wilkins. 1984: 38-70.

5. Armitage GC, Dickinson WR, Jenderseck RS, Levine SM, Chambers DW. Relationship between the percentage of subgingival spirochetes and the severity of periodontal disease. J Periodontol 1982; 53: 550-556.

6. Keyes PH, Rams TE. A rationale for management of periodontal diseases: rapid identification of microbial "therapeutic targets" with phase-contrast microscopy. $J$ Am Dent Assoc 1983; 106: 803-812.

7. Lindhe J, Liljenberg B, Listgarten M. Some microbiological and histopathological features of periodontal disease in man $J$ Periodontol 1980; 51: 264-269.

8. Listgarten MA. Structure of the microbial flora associated with periodontal health and disease in man. A light and electron microscopic study. J Periodontol 1986; 57: 1-18.

9. Listgarten MA, Lindhe JL, Helldén L. Effect of tetracycline and/or scaling on human periodontal disease. Clinical microbiological and histological observations $J$ Clin Periodontal 1978; 5: 246-271.

10. Löe $\mathrm{H}$, Theilade E, Jensen SB. Experimental gingivitis in man. $J$ Periodontol 1965; 36: 177-187.

11. Loesche WJ, Laughon B. Role of spirochetes in periodontal disease. In: Genco RJ, Mergenhagen SE (eds) Hostparasite interactions in periodontal disease. Washington, DC, American Society for Microbiology 1982: 62 .

12. Loesche WJ, Syed SA, Schmidt E, Morrison EC. Bacterial profiles of subgingival plaques in periodontitis. $J$ Periodontol 1985; 56: 447-456.

13. Moore WEC, Holdeman LV, Smibert RM et al. Bacteriology of experimental gingivitis in young adult humans. Infect Immun 1982; 38: 651-667.

14. Theilade E, Wright WW, Börglum-Jensen S, Löe H. Experimental gingivitis in man. II. A longitudinal, clinical, and bacteriological investigation. J Periodont Res 1966; 1 : $1-17$

15. Listgarten MA, Mayo HE, Tremblay R. Development of dental plaque on epoxy resin crowns in man. A light and electron microscope study. $J$ Periodontol 1975; 46: 10-26.

16. Page RC, Schroeder HE (eds). Periodontitis in man and other animals. A comparative review. Basel, Kager. 1982:225

17. Listgarten MA, Socransky SS. Ultrastructural characteristics of a spirochete in lesions of acute necrotizing ulcerative
Immunogold labelling of $T$. denticola ATCC 33520 with eluted antibodies proved specific for the $\mathrm{OM}$ and not periplasmic flagella. It is difficult to reconcile these findings with those of Simonson et al. ${ }^{26}$ who did not indicate which epitope was immunogold-labelled. We found that $T$. denticola ATCC 33521 possesses a $56-58-\mathrm{kDa}$ antigen which was recognised by the eluted antibodies (fig. 4). It seems possible that the $\mathrm{OM}$ epitope reported by Simonson et al. ${ }^{26}$ and the 56-58$\mathrm{kDa}$ antigen recognised in our study may be one and the same.

We thank Judy Pennington of the Department of Microbiology, University of Maryland Dental School, Baltimore, MD, for her clerical expertise over the years in the preparation of reports, abstracts and manuscripts related to this material. gingivitis (Vincent's disease). Arch Oral Biol 1964; 9 : 95-101.

18. Saglie R, Newman MG, Carranza FA Jr, Pattison GL. Bacterial invasion of gingiva in advanced periodontitis in humans. $J$ Periodontol 1982; 53: 217-222.

19. Fiehn NE. Enzyme activities from eight small-sized oral spirochetes. Scand J Dent Res 1986; 94: 132-140.

20. Laughon BE, Syed SA, Loesche WJ. API ZYM system for identification of Bacteroides spp., Capnocytophaga spp. and spirochetes of oral origin. J Clin Microbiol 1982; 15 97-102.

21. Siboo R, Al-Joburi W, Gornistsky M, Chan ECS. Synthesis and secretion of phospholipase $\mathrm{C}$ by oral spirochetes. $J$ Clin Microbiol 1989; 27: 568-570.

22. Barbour AG, Tessier SL, Todd WJ. Lyme disease spirochetes and Ixodid tick spirochetes share a common surface antigenic determinant defined by a monoclonal antibody. Infect Immun 1983; 41 : 795-804.

23. Alderete JF, Baseman JB. Surface-associated host proteins on virulent Treponema pallidum. Infect Immun 1979; 26: 1048-1056.

24. Penn CW, Rhodes JG. Surface-associated antigens of Treponema pallidum concealed by an inert outer layer. Immunol 1982; 46: 9-16.

25. Masuda K, Kawata T. Isolation, properties, and reassembly of outer sheath carrying a polygonal array from an oral treponeme. J Bacteriol 1982; 150: 1405-1413.

26. Simonson LG, Rouse RF, Bockowski SW. Monoclonal antibodies that recognize a specific surface antigen of Treponema denticola. Infect Immun 1988; 56: 60-63.

27. Umemoto T, Namikawa I, Suido H, Asai S. A major antigen on the outer envelope of a human oral spirochete, Treponema denticola. Infect Immun 1988; 57: 2470-2474.

28. Jacob E, Allen AL, Nauman RK. Detection of oral anaerobic spirochetes in dental plaque by the indirect fluorescentantibody technique. J Clin Microbiol 1979; 10: 934-936.

29. Tall BD, Nauman RK. Microscopic agglutination and polyacrylamide gel electrophoresis analysis of oral anaerobic spirochetes. J Clin Microbiol 1986; 24: 282-287.

30. Jacob E, Nauman RK. Common antigens of Treponema denticola. Chemical, physical, and serological characterization. Infect Immun 1982; 37: 474-480.

31. Weber K, Osborn $\mathbf{M}$. The reliability of molecular weight determinations by dodecyl sulfate-polyacrylamide gel electrophoresis. J Biol Chem 1969; 244: 4406-4412.

32. Towbin H, Staehelin T, Gordon J. Electrophoretic transfer of proteins from polyacrylamide gels to nitrocellulose sheets: procedure and some applications. Proc Natl Acad Sci USA $1979 ; 76: 4350-4354$

33. Tsang VCW, Peralta JM, Simons AR. Enzyme-linked immunoelectrotransfer blot techniques (EITB) for studying the specificities of antigens and antibodies separated by gel electrophoresis. In: Langone JJ, Van Vunakis H (eds) Methods in enzymology, vol 92; Immunological techniques pt E. New York, Academic Press. 1983: 377-391.

34. Wolff JW. The laboratory diagnosis of leptospirosis. In 
Dalldorf Gilbert (eds) American lectures in tests and technique. Springfield, IL, Charles C Thomas. 1954: 51.

35. Engleberg NC, Pearlman E, Eisenstein BI. Legionella pneumophila surface antigens cloned and expressed in Escherichia coli are translocated to the host cell surface and interact with specific anti-Legionella antibodies. J Bacteriol 1984 ; 160: 199-203.

36. Jacob E, Carter TB, Nauman RK. Immunological relationship among oral anaerobic spirochetes as detected by indirect microhemagglutination. J Clin Microbiol 1980; 12 610-613.

37. Jacob E, Meiller TF, Nauman RK. Detection of elevated serum antibodies to Treponema denticola in humans with advanced periodontitis by an enzyme-linked immunosorbent assay. J Periodont Res 1982; 17: 145-153.

38. Lowry OH, Rosebrough NJ, Farr AL, Randall RJ. Protein measurement with the folin phenol reagent. $J$ Biol Chem 1951; 193: 265-275.

39. Tall BD, Nauman RK. Abstracts of the Annual Meeting of the American Society for Microbiology 1984: 128.

40. Kropinski AM, Parr TR, Angus BL, Hancock REW, Ghiorse WC, Greenberg EP. Isolation of the outer membrane and characterization of the major outer membrane protein from Spirochaeta aurantia. J Bacteriol 1987; 169: 172-179.
41. Walker EM, Zampighi GA, Blanco DR, Miller JN, Lovett MA Demonstration of rare protein in the outer membrane of Treponema pallidum subsp. pallidum by freeze-fracture analysis. J Bacteriol 1989; 171: 5005-5011.

42. Cockayne A, Sanger R, Ivic A et al. Antigenic and structural analysis of Treponema denticola. J Gen Microbiol 1989; 135: 3209-3218.

43. Yotis WW, Sharma VK, Gopalsami C et al. Biochemical properties of the outer membrane of Treponema denticola. J Clin Microbiol 1991; 29: 1397-1406.

44. Weinberg A, Holt SC. Chemical and biological activities of a 64-kilodalton outer sheath protein from Treponema denticola strains. J Bacteriol 1991; 173: 6935-6947.

45. Haapsalo M, Müller KH, Uitto V-J, Leung WK, McBride BC. Characterization, cloning, and binding properties of the major 53-kilodalton of Treponema denticola surface antigen. Infect Immun 1992; 60: 2058-2065.

46. Tall BD, Nauman RK. Abstracts of the Annual Meeting of the American Society for Microbiology 1985: 169.

47. Umemoto T, Zambon JJ, Genco RJ, Nsamikawa I. Major antigens of the human oral spirochetes associated with periodontal disease. Adv Dent Res 1988; 2: 292-296.

48. Umemoto T, Namikawa I, Suido H, Asai S. A major antigen on the outer envelope of a human oral spirochete, Treponema denticola. Infect Immun 1989; 57: 2470-2474. 